\title{
Characterization of $n d h$ gene of isoniazid resistant and susceptible Mycobacterium tuberculosis isolates from Brazil
}

\author{
Rosilene Fressatti Cardoso/ ${ }^{+}$, Marco Antonio Cardoso, Clarice Queico Fujimura Leite*, \\ Daisy Nakamura Sato**, Elsa Masae Mamizuka***, \\ Rosário Dominguez Crespo Hirata***, Fernando Fiúza de Mello****, \\ Mario Hiroyuki Hirata***
}

\begin{abstract}
Laborartório de Bacteriologia Clínica, Departamento de Análises Clínicas, Universidade Estadual de Maringá, Av. Colombo 5790 , Bloco J-90, Jardim Universitário, 87020-900 Maringá, PR, Brasil *Departamento de Ciências Biológicas, Unesp, Araraquara, SP, Brasil **Instituto Adolfo Lutz, Ribeirão Preto, SP, Brasil ***Universidade de São Paulo, São Paulo, SP, Brasil ****Instituto Clemente Ferreira, São Paulo, SP, Brasil
\end{abstract}

Resistance in Mycobacterium tuberculosis to isoniazid (INH) is caused by mutations in the catalase-peroxidase gene (katG), and within the inhA promoter and/or in structural gene. A small percentage ( 10\%) of INHresistant strains do not present mutations in both of these loci. Other genes have been associated with INH resistance including the gene encoding for $\mathrm{NADH}$ dehydrogenase (ndh). Here we report the detection of two ndh locus mutations (CGT to TGT change in codon 13 and GTG to GCG change in codon 18) by analyzing 23 INHresistant and in none of 13 susceptible isolates from Brazilian tuberculosis patients. We also detected two isolates without a mutation in $\mathrm{ndh}$, or any of the other INH resistance-associated loci examined, suggesting the existence of additional, as yet to be described, INH resistance mechanisms.

Key words: Mycobacterium tuberculosis - NADH dehydrogenase gene - isoniazid resistance

Isoniazid (INH) has been a first-line drug for tuberculosis treatment for many years and yet its mechanism of action remains only partially understood (Rozwarski et al. 1998, Heym et al. 1999). Molecular studies have demonstrated that mutations in $k a t G$ and inhA (regulatory and structural regions) confer resistance to INH in Mycobacterium tuberculosis (Telenti 1998). Mutations in $\operatorname{oxy} R-\operatorname{ahpC}$ intergenic region are considered a compensatory mechanism for the loss of KatG enzyme activity in resistant strains (Sherman et al. 1996, Ramaswamy \& Musser 1998) and can be used as a surrogate marker for detection of resistance to INH in $M$. tuberculosis (Wilson et al. 1998). Other putative mechanisms that can result in resistance to INH are less well understood (Zang \& Telenti 2000, Larsen et al. 2002).

Prior studies (Chen \& Bishai 1998, Miesel et al. 1998) have postulated the involvement of the $n d h$ gene in resistance to INH and ethionamide (ETH) in $M$. smegmatis. Mutations in this gene result in diminishment of NADH oxidation and consequently an increase in NADH concentration and depletion of NAD+. This alteration of the NADH/NAD+ ratio than prevents the peroxidation reactions required for the activation of INH, as well as the displacement of the NADH-isonicotinic acyl complex from InhA enzyme binding site. In order to evaluate the contribution of the $n d h$ gene to INH re-

Financial support: Fapesp, Capes

${ }^{+}$Corresponding author: rfcardoso@uem.br

Received 6 July 2006

Accepted 14 November 2006 sistance in M. tuberculosis, Lee et al. (2001) sequenced the entire $n d h$ gene of 84 INH-resistant and 22 susceptible M. tuberculosis isolates. This study identified two distinct mutations in eight INH- resistant isolates (T110A and $\mathrm{R} 268 \mathrm{H}$ ), while no mutations were detected in susceptible isolates. Recently, $n d h$ mutants of $M$. bovis $\mathrm{BCG}$ were shown to be low-level resistant to INH and ETH (Vilchèze et al. 2005). These mutants had increased intracellular NADH/NAD+ ratios and, upon complementation with the wild-type $n d h$ gene, full susceptibility to both INH and ETH was restored. In this sense, we investigated the presence of $n d h$ mutations among INH-resistant and susceptible M. tuberculosis clinical isolates from Brazil. We studied 23 INH-resistant and 13 susceptible M. tuberculosis clinical isolates from the culture collections of the Institute Adolfo Lutz of Ribeirão Preto, Institute Adolfo Lutz of Sorocaba, Institute Clemente Ferreira, state of São Paulo, and Clinical Bacteriology Laboratory, Department of Clinical Analysis, state of Paraná, Brazil. All isolates had previously been identified by biochemical test (Kent \& Kubica 1985) and genotyped using the spoligotyping method (Molluizen et al. 1998). Susceptibility to INH was determined using the proportion method in LöwensteinJensen medium (BD/Becton, Dickinson and Co. Sparks, MD, US) according to Canetti et al. (1963). The minimal inhibitory concentration (MIC) of INH was determined for all isolates using the Microplate Alamar Blue Assay (MABA) (Franzblau et al. 1998). The isolates were cultured in Middlebrook 7H9 broth with oleic acid-albumin-dextrose-catalase (OADC) Enrichment (BBL/ Becton, Dickinson) containing two-fold serial dilution of INH, ranging from 32.0 to $0.25 \mu \mathrm{g} / \mathrm{ml}$. The visual MIC value was defined as the lowest INH concentration that 
prevented a color change of the Alamar Blue reagent (Accumed International, Westlake, OH, US) from blue to pink. A blue color in the well was interpreted as absent (inhibit grow-up of 90\%) of mycobacterial growing. According to Franzblau et al. (1998), in this study, the $M$. tuberculosis isolates were considered susceptible to INH when showed MIC value $\leq 0.25 \mu \mathrm{g} / \mathrm{ml}$.

In all isolates studied here, an earlier report describes the genotypic analysis by polymerase chain reactionsingle-strand conformation polymorphism analysis (PCR-SSCP) targeting the codons 16 (region - 7 to 67) and 94 (region 65 to 125) of inhA, the oxyR-ahpC intergenic region and the entire kas $A$ gene by amplifying six overlapping fragments. Sequencing was performed of the genes fragments that presented PCR-SSCP patterns different from wild type ones and of the entire $k a t G$ gene of all strains studied in this work (Cardoso et al. 2004).

The chromosomal DNA was extracted as described earlier (Gonzalez-y-Merchand et al. 1996) with modifications introduced in our laboratory (Cardoso et al. 2004). The entire $n d h$ gene was PCR amplified in five overlapping fragments according to Lee et al. (2001). The PCR products were generated using the Hotstart $\mathrm{Taq}^{\mathrm{TM}}$ Master Kit (Qiagen Inc. Valencia, CA, US) according to the manufacturer's instructions with $1 \mu \mathrm{l}$ of template genomic DNA in a final reaction volume of 25 $\mu l$ in a Gene Amp System 2400 thermalcycler (PE Applied Biosystems Corp., Foster City, CA, US). Sequencing reactions were performed using the $\mathrm{ABI}$ Prism BigDye terminator Cycle Sequencing Kit (PE Applied Biosystems Corp.) according to the manufacturer's instructions in a Gene Amp PCR System 9700 ther-malcyrcler (PE Applied Biosystems Corp.). Sequencing products were purified using CENTRI-SEP Colums (Princeton Separations, Inc. Adelphia, NJ, US) and electrophoresed on an ABI Prism 373XL automatic sequencer (PE Applied Biosystems Corp.). Sequence data were assembled and edited electronically using ABI PRISM DNA Sequencing Analysis Software version 3.0 (PE Applied Biosystem Corp.) and the results compared to the sequence for $n d h$ of M. tuberculosis H37Rv present in GeneBank (acession no. Z838559).

From the 23 INH-resistant $M$. tuberculosis clinical isolates studied, $n d h$ gene mutations were detected in two (8.7\%) and no mutation was detected in the $13 \mathrm{INH}-$ susceptible isolates (Table). One isolate (INH MIC > $32.0 \mu \mathrm{g} / \mathrm{ml}$ ) presented mutation in codon 13 (CGT to TGT), resulting in an $\mathrm{R}_{13} \mathrm{C}$ amino acid change and in other (INH MIC $32.0 \mathrm{mg} / \mathrm{ml}$ ) the mutation was in codon 18 (GTG to GCG) resulting in a $\mathrm{V}_{18} \mathrm{~A}$ amino acid change. The $\mathrm{R}_{13} \mathrm{C}$ mutations detected in our work occurred at different locations from those previously reported $n d h$ either in M. smegmatis (Chen \& Bishai 1998, Miesel et al. 1998) or in clinical isolates of M. tuberculosis (Lee et al. 2001, Ramaswamy et al. 2003) but the $\mathrm{V}_{18}$ A mutation was reported by Ramaswamy et al. (2003) in susceptible M. tuberculosis isolates.

It was verified that both INH-resistant isolates, that presented mutation in $n d h$, also had a mutation in katG (one of them with point mutation in codon no. 315 , re- sulting in a $\mathrm{S}_{315} \mathrm{~T}$ and in the other isolate, insertion of $\mathrm{A}$ at nucleotide position 17 of $\mathrm{kat} G$ ) detected in our previous study (Cardoso et al. 2004). According to Ramaswamy and Musser (1998), Zhang and Telenti (2000), van Soolingen et al. (2002), isolates with katG mutation, show MIC value consistent with of the INH-resistant isolates, suggesting that resistance was due to mutation in katG. In this sense, the contribution of $n d h$ mutation to the INH resistance phenotype is unknown. Considering the recent demonstration that mutations in the $n d h$ gene of $M$. bovis BCG mediate INH and ETH resistance (Vilchèze et al. 2005) it seems probable that such mutation could have a similar effect in $M$. tuberculosis. The $\mathrm{R}_{13} \mathrm{C} n d h$ mutants identified in this study might prove useful in demonstrating the involvement of this mechanism in $M$. tuberculosis. Further investigation is needed to establish the role and prevalence of $n d h$ mu-

TABLE

Results of minimal inhibitory concentration (MIC) value and $n d h$ genotypic analysis for 36 Mycobacterium tuberculosis clinical isolates from Brazil

\begin{tabular}{lcc}
\hline Isolates & MIC $\mu \mathrm{g} / \mathrm{ml}$ & $n d h$ \\
\hline 470 & 1.0 & $\mathrm{WT}$ \\
5269 & 2.0 & $\mathrm{WT}$ \\
25 & 2.0 & $\mathrm{WT}$ \\
309 & 16.0 & $\mathrm{WT}$ \\
531 & 16.0 & $\mathrm{WT}$ \\
$64 \mathrm{~A}$ & 16.0 & $\mathrm{WT}$ \\
$116 / 00$ & 16.0 & $\mathrm{WT}$ \\
106 & 32.0 & $\mathrm{WT}$ \\
$3446 / 00$ & 32.0 & $\mathrm{WT}$ \\
1091 & 32.0 & $\mathrm{WT}$ \\
503 & 32.0 & $\mathrm{~V} 18 \mathrm{~A}$ \\
$44 \mathrm{~A}$ & $>32.0$ & $\mathrm{WT}$ \\
$57 \mathrm{~A}$ & $>32.0$ & $\mathrm{WT}$ \\
227 & $>32.0$ & $\mathrm{WT}$ \\
$3408 / 00$ & $>32.0$ & $\mathrm{WT}$ \\
$3614 / 00$ & $>32.0$ & $\mathrm{WT}$ \\
$3401 / 00$ & $>32.0$ & $\mathrm{R} 13 \mathrm{C}$ \\
$211-\mathrm{S}$ & $>32.0$ & $\mathrm{WT}$ \\
$148-\mathrm{S}$ & $>32.0$ & $\mathrm{WT}$ \\
2542 & $>32.0$ & $\mathrm{WT}$ \\
5355 & $>32.0$ & $\mathrm{WT}$ \\
4509 & $>32.0$ & $\mathrm{WT}$ \\
$46-\mathrm{S}$ & $>32.0$ & $\mathrm{WT}$ \\
4851 & $\mathrm{~S}$ & $\mathrm{WT}$ \\
36 & $\mathrm{~S}$ & $\mathrm{WT}$ \\
5039 & $\mathrm{~S}$ & $\mathrm{WT}$ \\
405 & $\mathrm{~S}$ & $\mathrm{WT}$ \\
1778 & $\mathrm{~S}$ & $\mathrm{WT}$ \\
17433 & $\mathrm{~S}$ & $\mathrm{WT}$ \\
6230 & $\mathrm{~S}$ & $\mathrm{WT}$ \\
7188 & $\mathrm{~S}$ & $\mathrm{WT}$ \\
1997 & $\mathrm{~S}$ & $\mathrm{WT}$ \\
3693 & $\mathrm{~S}$ & $\mathrm{WT}$ \\
17711 & $\mathrm{~S}$ & $\mathrm{WT}$ \\
1235 & $\mathrm{~S}$ & $\mathrm{WT}$ \\
11181 & & $\mathrm{WT}$ \\
\hline & & \\
\hline $\mathrm{n}$ & &
\end{tabular}

$a$ : novel mutation; WT: wild type (the entire gene was sequenced and no mutation was found); S: susceptible. 
tations in a larger number of INH-resistant M. tuberculosis clinical isolates.

Two INH-resistant isolates studied here (INH MIC 2.0 and $>32.0 \mu \mathrm{g} / \mathrm{ml}$ ) that showed no mutation in $n d h$ genes also were negative to $\operatorname{kat} G, \operatorname{inh} A, \operatorname{kas} A$, or in the oxy $R$-ahpC intergenic region mutation in the previous study (Cardoso et al. 2004). This suggests the existence of additional INH resistance mechanism. These isolates are therefore good candidates for further investigation of alternative mechanisms.

\section{ACKNOWLEDGMENTS}

To Glenn Paul Morlock and Robert Cannon Cooksey (Division of AIDS, STD, and TB Laboratory Research, National Center for HIV, STD, and TB Prevention, Centers for Disease Control and Prevention, Atlanta, Georgia) for their collaboration in interpretation of data, suggestion, and critical comments on the manuscript.

\section{REFERENCES}

Canetti G, Rist N, Grosset J 1963. Mésure de la sensibilité du bacilli tuberculeux aux drogues antibacilares par la méthode des proportions. Rev Tuberc Pneumol 27: 217-272.

Cardoso RF, Cooksey RC, Morlock GP, Barco P, Cecon L, Forestiero F, Leite CQF, Sato DN, Shikama ML, Mamizuka EM, Hirata RDC, Hirata MH 2004. Screening and characterization of mutations in isoniazid-resistant Mycobacterium tuberculosis isolates obtained in Brazil. Antimicrob Agents Chemot 48: 3373-3381.

Chen P, Bishai WR 1998. Novel selection for Isoniazid (INH) resistance genes supports a role for NAD+ bidding proteins in mycobacterial INH resistance. Infect Immun 66: 50995106.

Franzblau SG, Witzig RS, McLaughlin JC, Torres P, Madico G, Hernandez A, Degnan MT, Cook MB, Quenzer VK, Ferguson RM, Gilman RH 1998. Rapid, low-technology MIC determination with clinical Mycobacterium tuberculosis isolates by using the microplate Alamar Blue Assay. J Clin Microbiol 36: 362-366.

Gonzales-Y-Merchand JA, Estrada-Garcia I, Colston MJ, Cox RA 1996. A novel method for the isolation of mycobacterial DNA. FEMS Microbiol Lett 135: 71-77.

Heym B, Saint-Joanis B, Cole ST 1999. The molecular basis of isoniazid resistance in Mycobacterium tuberculosis. Tubercle Lung Dis 79: 267-271.

Kent PT, Kubica GP 1985. Public Health Mycobacteriology. A Guide for the Level III Laboratory, U.S. Department of Health and Human Services, Washington, D.C, 207 pp.

Larsen MH, Vilcheze C, Kremer L, Bersa GS, Parsons L, Salfinger M, Heifets L, Hazbon MH, Alland D, Sacchettini JC, Jacobs WR 2002. Overexpression of inhA, but not kasA, confers resistance to isoniazid and ethionamide in Mycobacterium smegmatis, M. bovis BCG, and M. tuberculosis. Mol
Microbiol 46: 453-466.

Lee ASG, Teo ASM, Wong SY 2001. Novel mutations in $n d h$ in isoniazid-resistant Mycobacterium tuberculosis isolates. Antimicrob Agents Chemother 45: 2157-2159.

Miesel L, Weibrod TR, Marcinkeviciene JA, Bittman R, Jacobs Jr WR 1998. NADH dehydrogenase defects confer isoniazid resistance and conditional lethality in Mycobacterium tuberculosis. J Bacteriol 180: 2459-67.

Molhuizen HOF, Bunschoten AE, Schouls LM, Van Embden JDA 1998. Rapid detection and simultaneous strain differentiation of Mycobacterium tuberculosis complex bacteria by spoligotyping. In T Parish, NG Soker (eds), Methods in Molecular Biology, vol. 101: Mycobacteria Protocols, Humana Press, Totowa, NJ, p. 381-394.

Ramaswamy S, Musser JM 1998. Molecular genetic basis of antimicrobial agent resistance in Mycobacterium tuberculosis: update. Tubercle and Lung Disease 79: 3-29.

Ramaswamy SV, Reich R, Dou SJ, Jasperse L, Pan X, Wanger A, Quitugua T, Graviss EA 2003. Single nucleotide polymorphisms in genes associated with isoniazid resistance in $M y$ cobacterium tuberculosis. Antimicrob Agents Chemother 47: 1241-1250.

Rozwarski DA, Grant GA, Barton DHR, Jacobs WR, Sacchettini JC 1998. Modification of the NADH of the isoniazid target (InhA) from Mycobacterium tuberculosis. Science 279: 98-102.

Sherman DR, Mdluli K, Hickey MJ, Arain TM, Morris SL, Barry III CE, Stover CK 1996. Compensatory $a h p C$ gene expression in isoniazid-resistant Mycobacterium tuberculosis. Science 272: 1641-1643.

Telenti A 1998. Genetics of drug resistant tuberculosis. Thorax 53: 793-797.

Van Soolingen D, de Haas PE, van Doorn HR, Kuijper E, Rinder $\mathrm{H}$, Borgdorff MW 2000. Mutations at amino acid position 315 of the $K a t G$ gene are associated with high-level resistance to isoniazid, other drug resistance, and successful transmission of Mycobacterium tuberculosis in The Netherlands. J Infct Dis 182: 1788-1790.

Vilchèze C, Weisbrod TR, Chen B, Kremer L, Házbón HM, Wang F, Alland D, Sacchettini JC, Jacobs Jr WR 2005. Altered $\mathrm{NADH} / \mathrm{NAD}+$ ratio mediates coresistance to isoniazid and ethionamide in mycobacteria. Antimicrob Agents Chemother 49: 708-720.

Wilson T, Lisle GW, Marcinkeviciene JA, Blanchard JS, Collins DM 1998. Antisense RNA to ahpC, an oxidative stress defence gene involved in isoniazid resistance, indicates that AhpC of Mycobacterium bovis has virulence properties. Microbiology 144: 2687-2695.

Zhang Y, Telenti A 2000. Genetic of drug resistance in Mycobacterium tuberculosis. In GH Hatfull, W Jacobs (eds), Molecular Genetics of Mycobacteria, American Society for Microbiology, Washington D.C, p. 235-254. 